\title{
Potensi Perikanan Endemik Untuk Pembangunan Perikanan Berkelanjutan
}

M. Mukhlis Kamal

Departemen Manajemen Sumberdaya Perairan

Fakultas Perikanan dan Ilmu Kelautan, IPB University

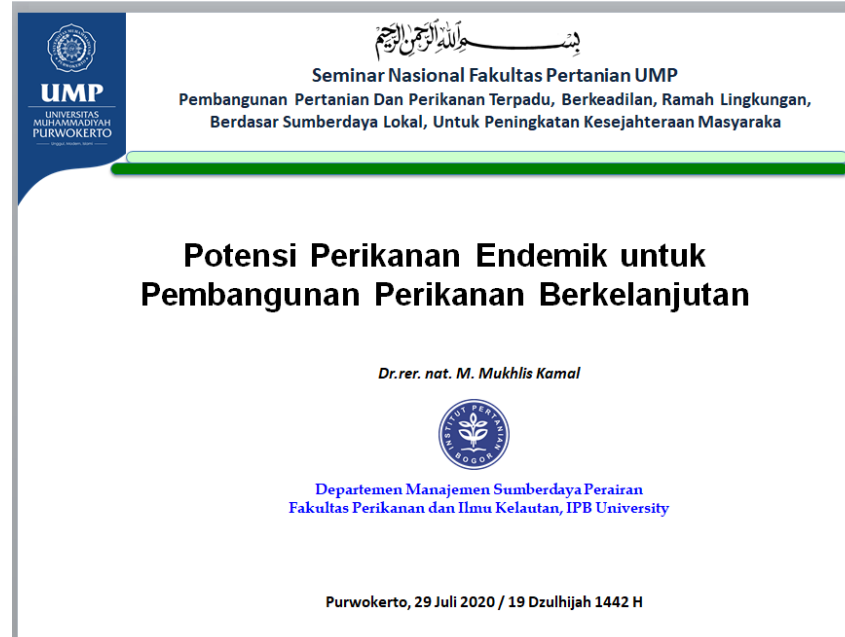

\section{Outline}

- Mengapa indonesia kaya akan spesies ikan? (tinjauan dari complex geological setting)

- Keberadaan ikan endemik di Indonesia: Pemanfatan dan permasalahan

- Strategi pemanfaatan berkelanjutan

- Pengelolaan ikan endemik dengan pendekatan lingkungan (balancing ecology-economy)

- Penutup

\section{Kekayaan jenis ikan Nusantara} (www.fishbase.org)

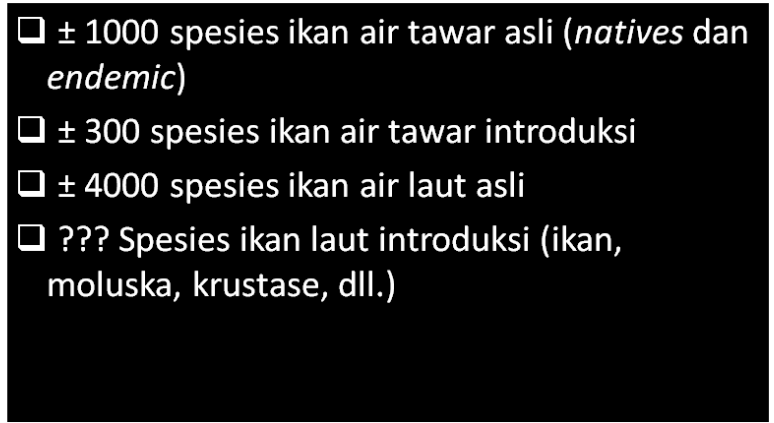


Indonesia kaya akan ikan endemik: a complex geological setting

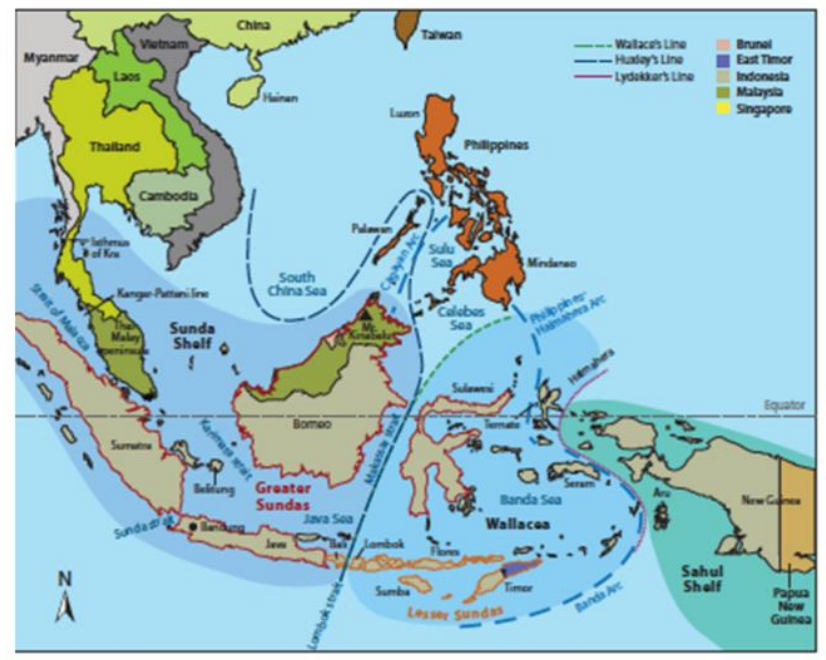

Sumber: Lohman et al. 2011

\section{Ikan endemik Indonesia}
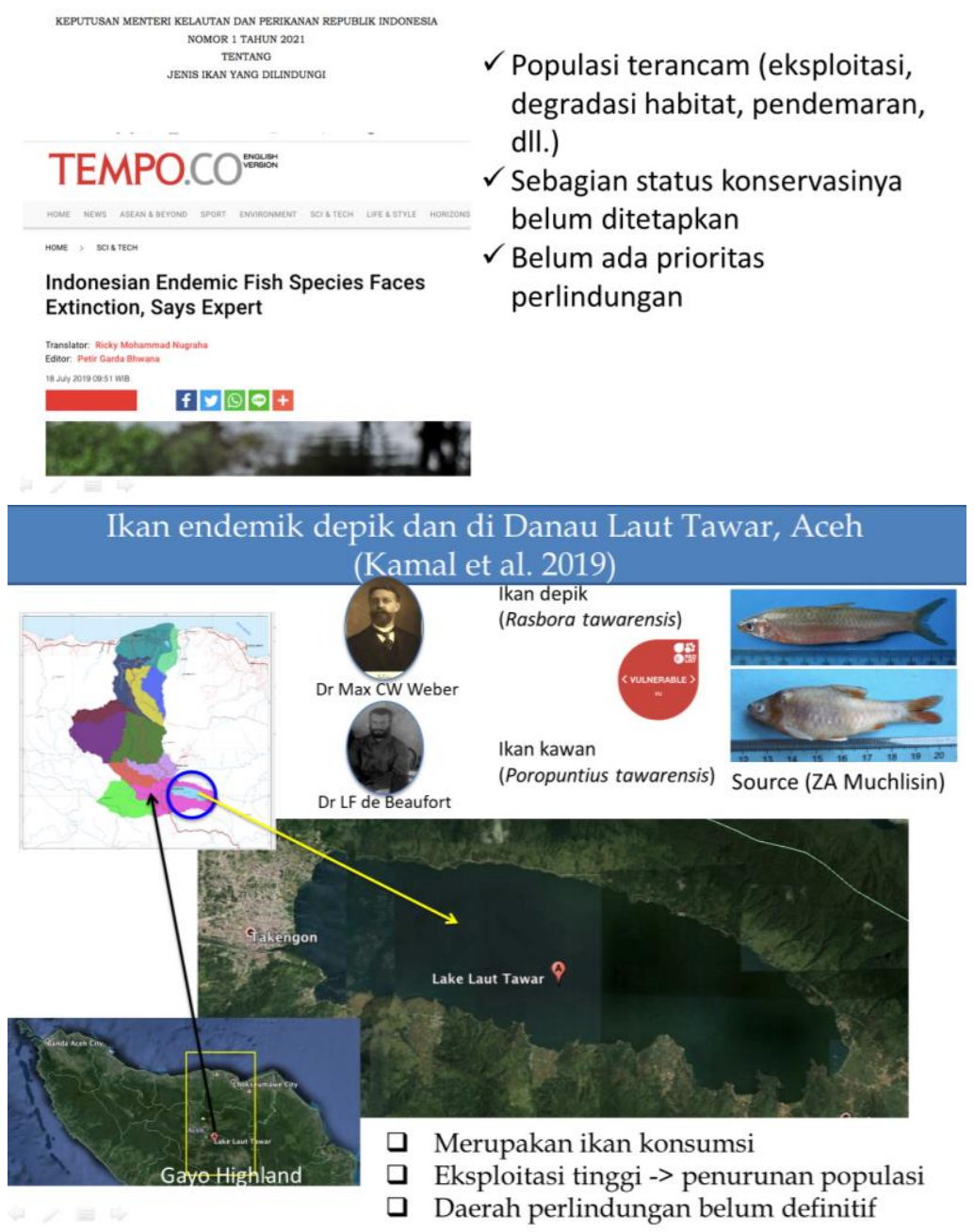

Proceedings homepage: https://conferenceproceedings.ump.ac.id/index.php/pspfs/issue/view/9 


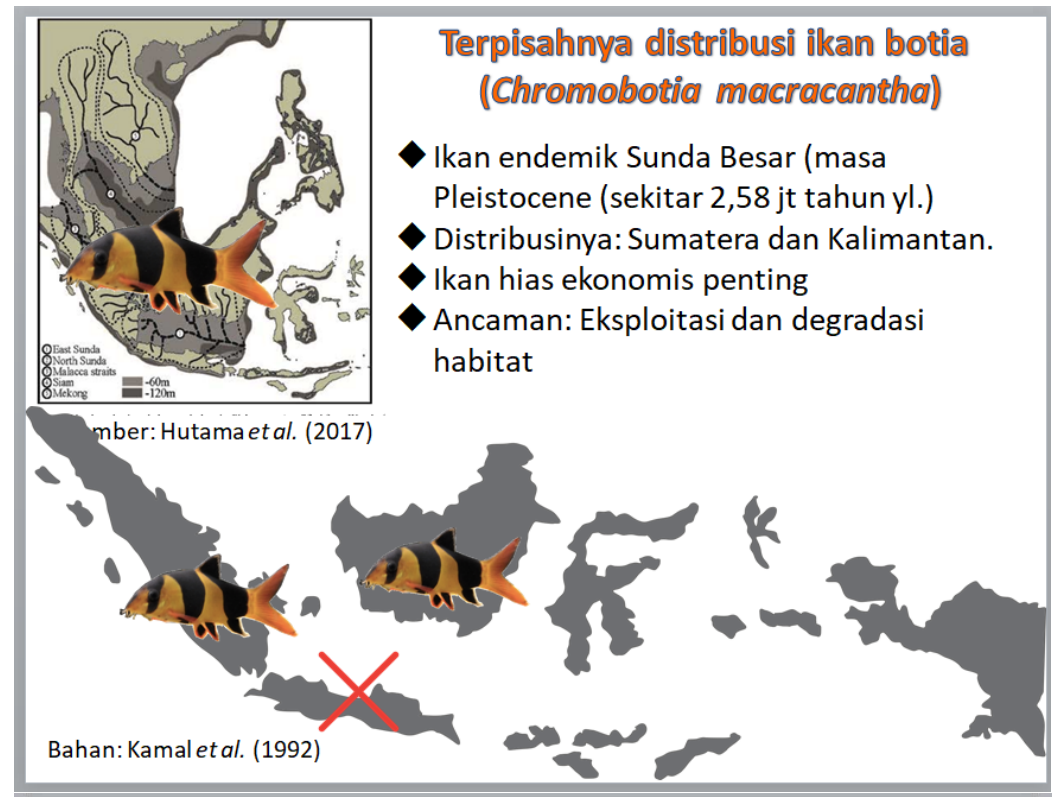

\section{Ikan bilih, Mystacoleucus padangensis (Bleeker, 1852)}
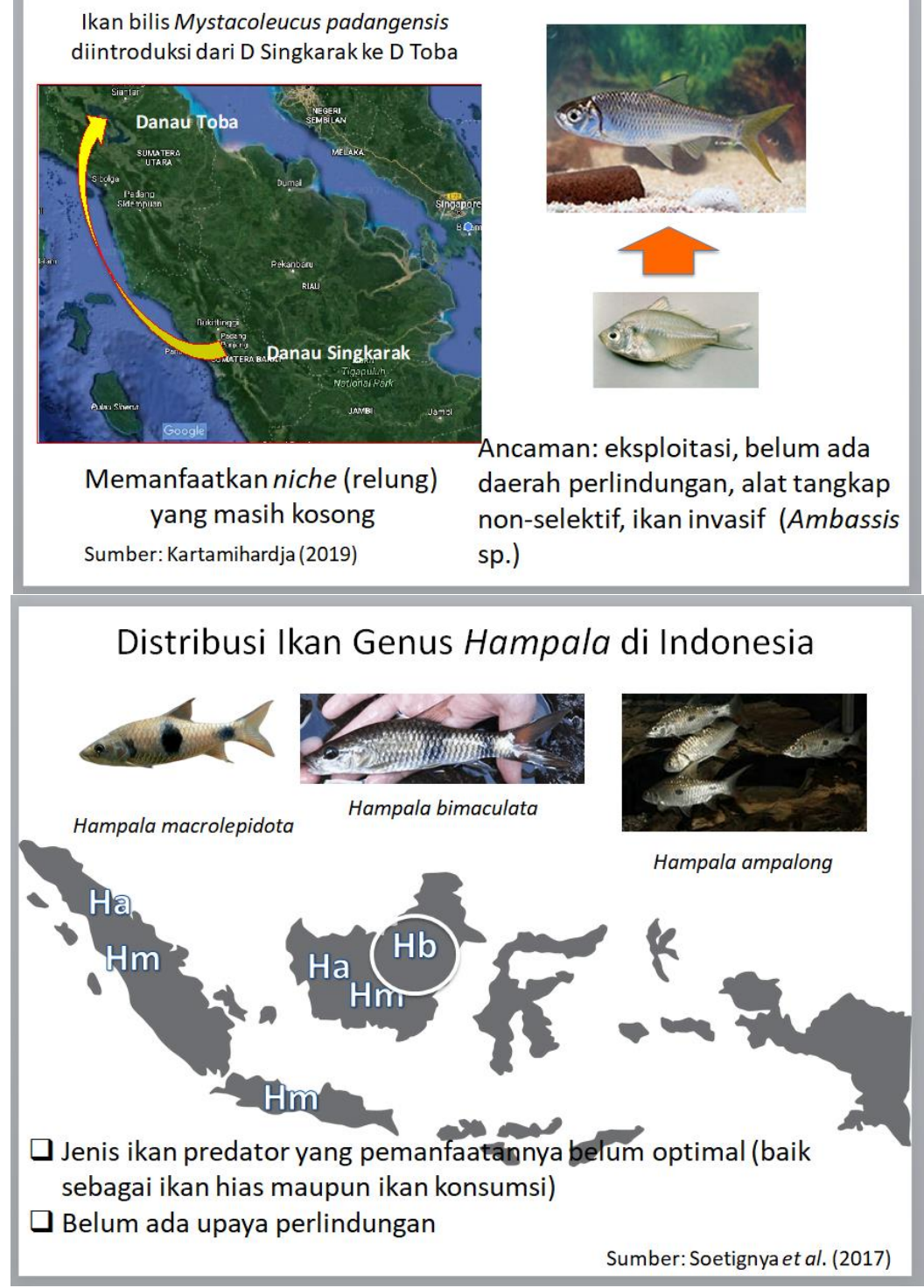

Proceedings homepage: https://conferenceproceedings.ump.ac.id/index.php/pspfs/issue/view/9 


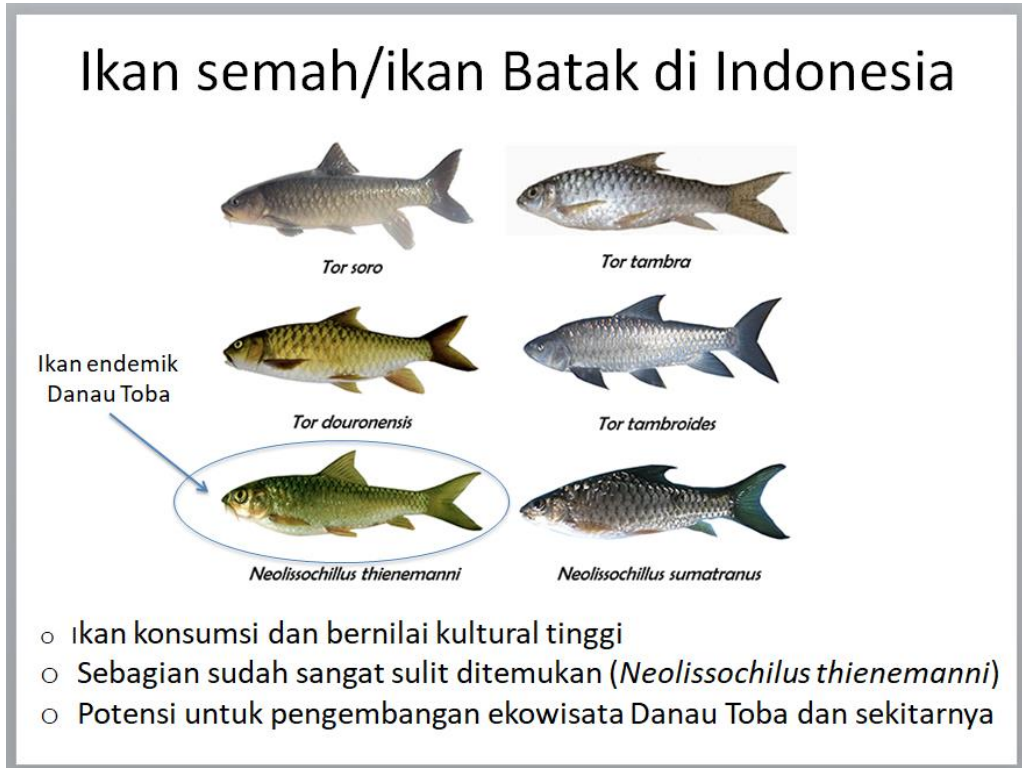

\section{Endemisitas ikan-ikan air tawar Sulawesi}

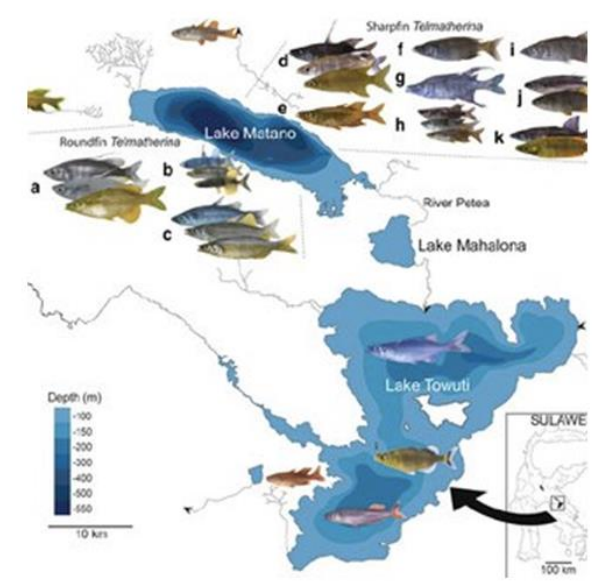

Hadiaty (2018):

terdapat 79 spesies ikan endemik di Pulau Sulawesi yang belum dikelola dengan baik

Permasalahan utama adalah degradasi habitat dan ikan invasif

Sumber: Herder et al. (2008)

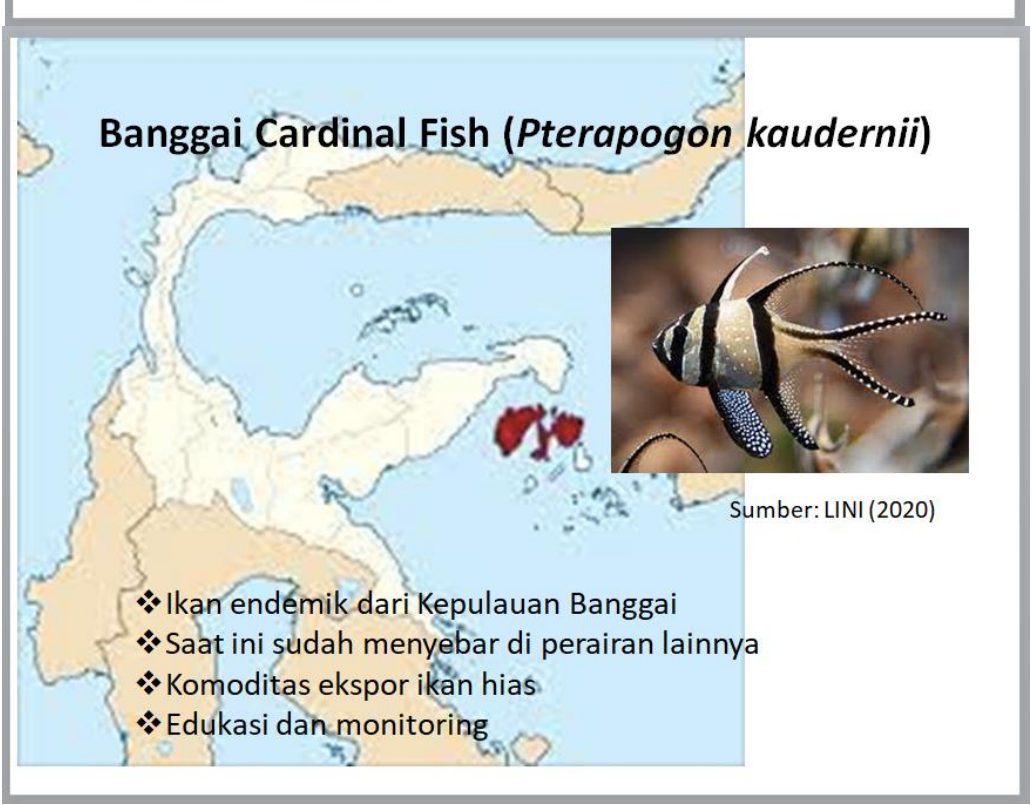




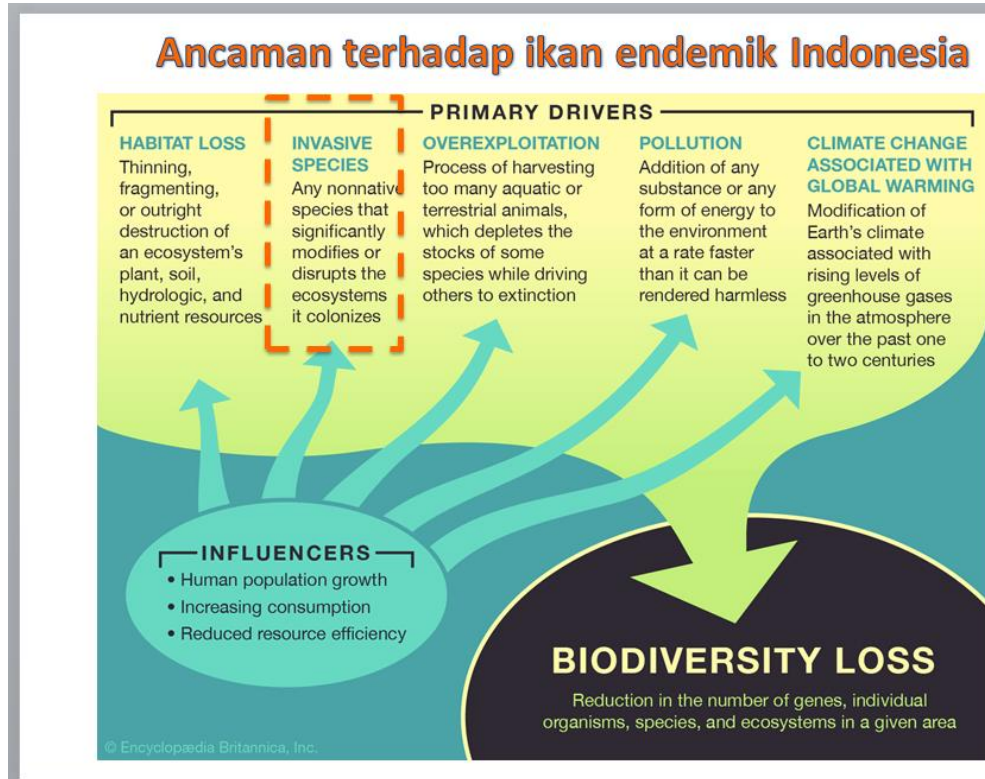

Ancaman Jenis ikan invasif (pangan, ikan hias, dan pengendali gulma
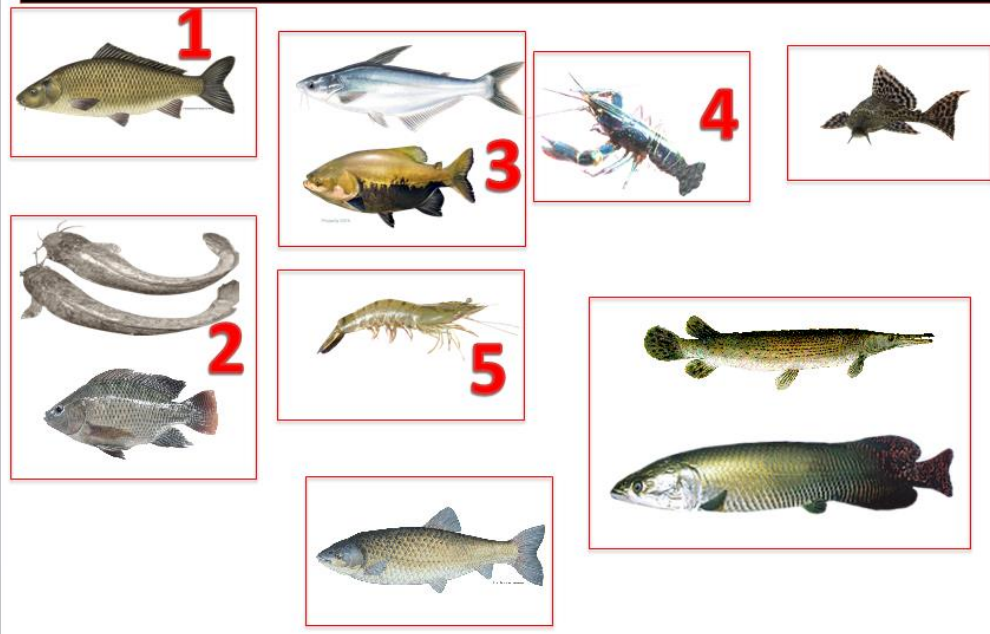

Invasifisme dalam wilayah NKRI Lobster air tawar: Cherax quadricarinatus

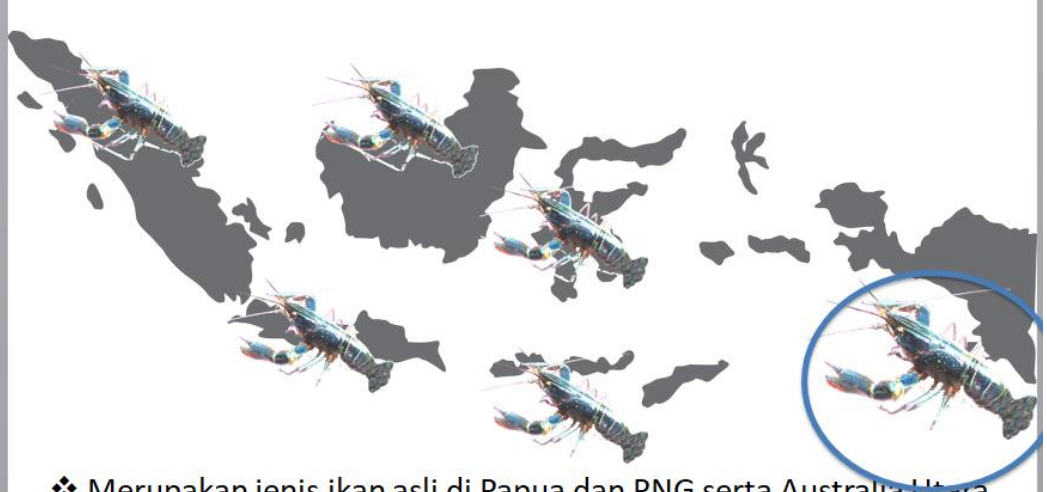

* Merupakan jenis ikan asli di Papua dan PNG serta Australra Utara * Introduksi budidaya ke perairan umum, sekarang menjadi invasif 


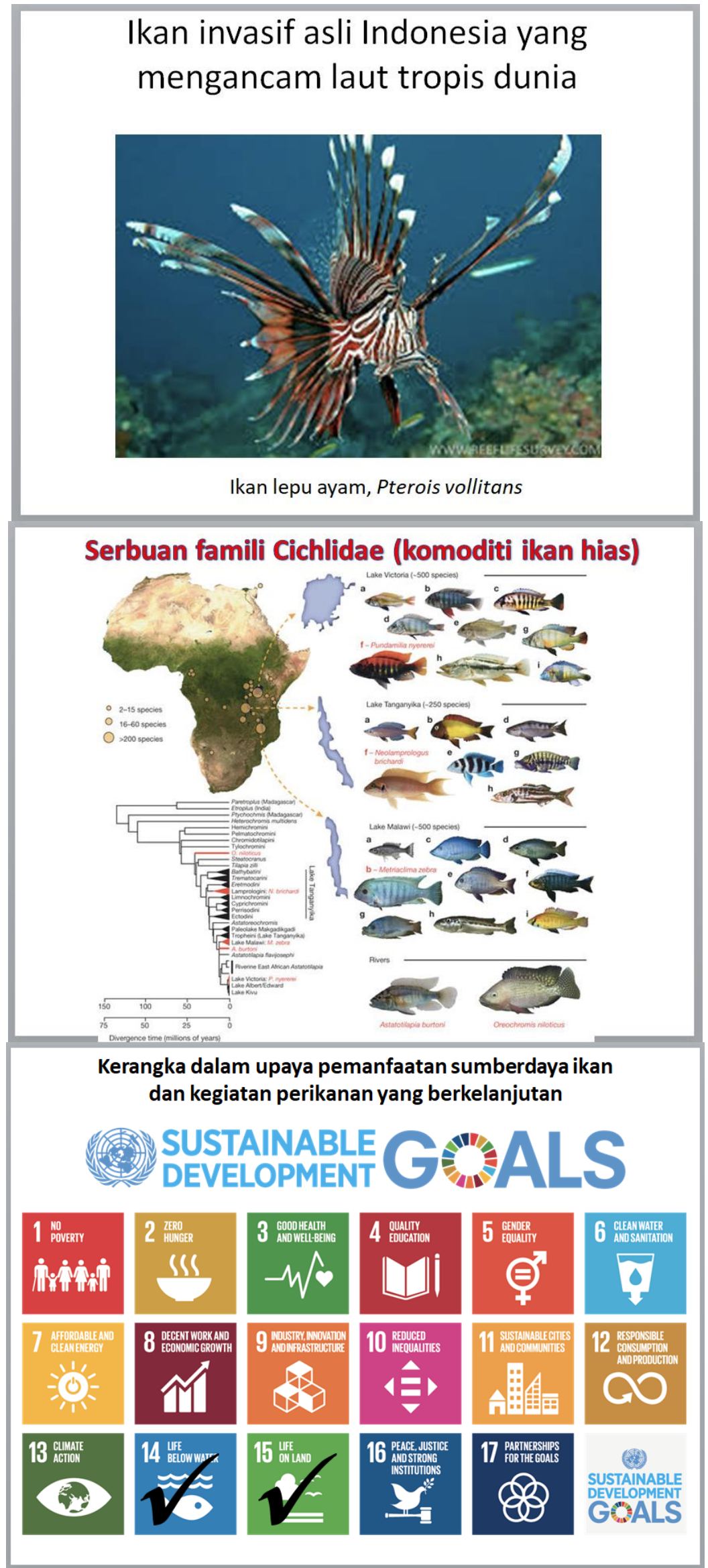




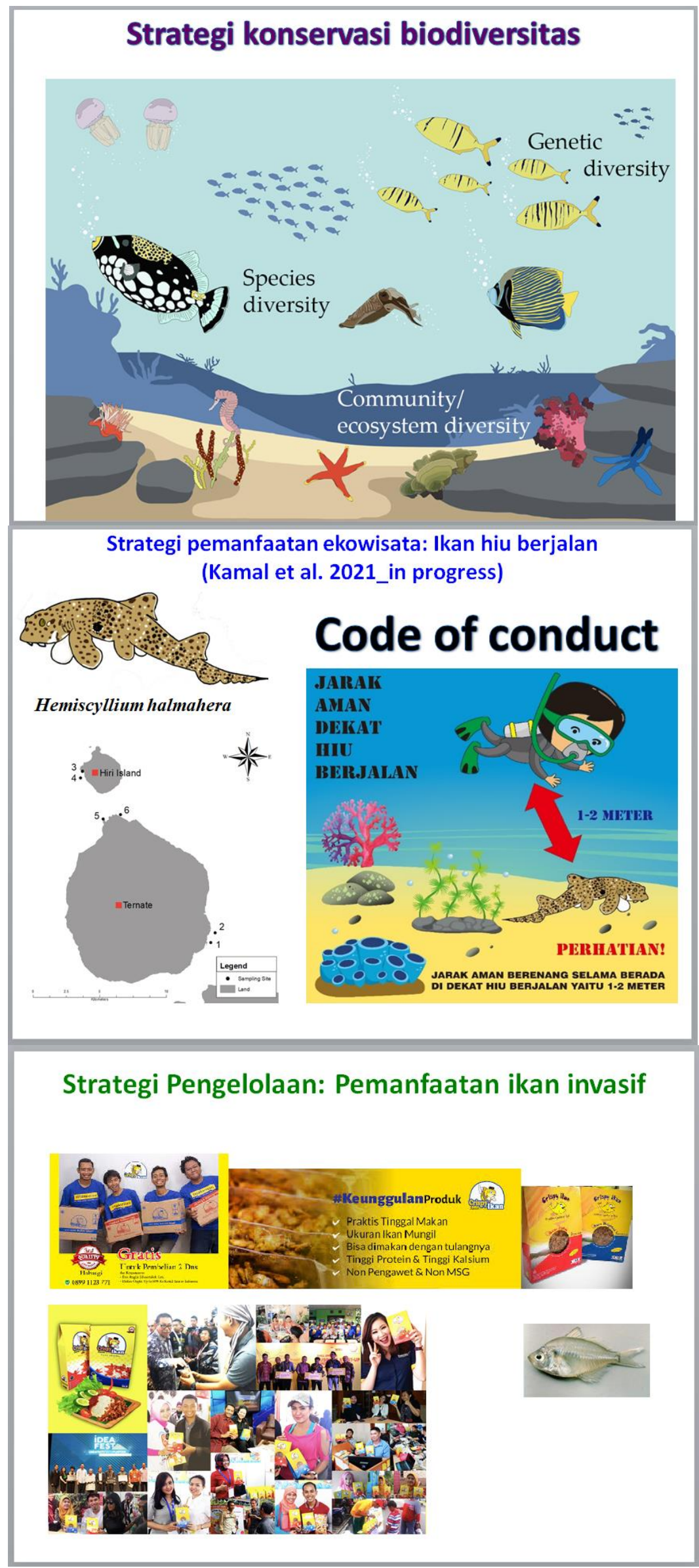

Proceedings homepage: https://conferenceproceedings.ump.ac.id/index.php/pspfs/issue/view/9 
Stategi pengelolaan dengan pendekatan ekosistem (EAFM)

Ecosystem approach applicability to sustain endemic fishes in

Lake Laut Tawar, Aceh

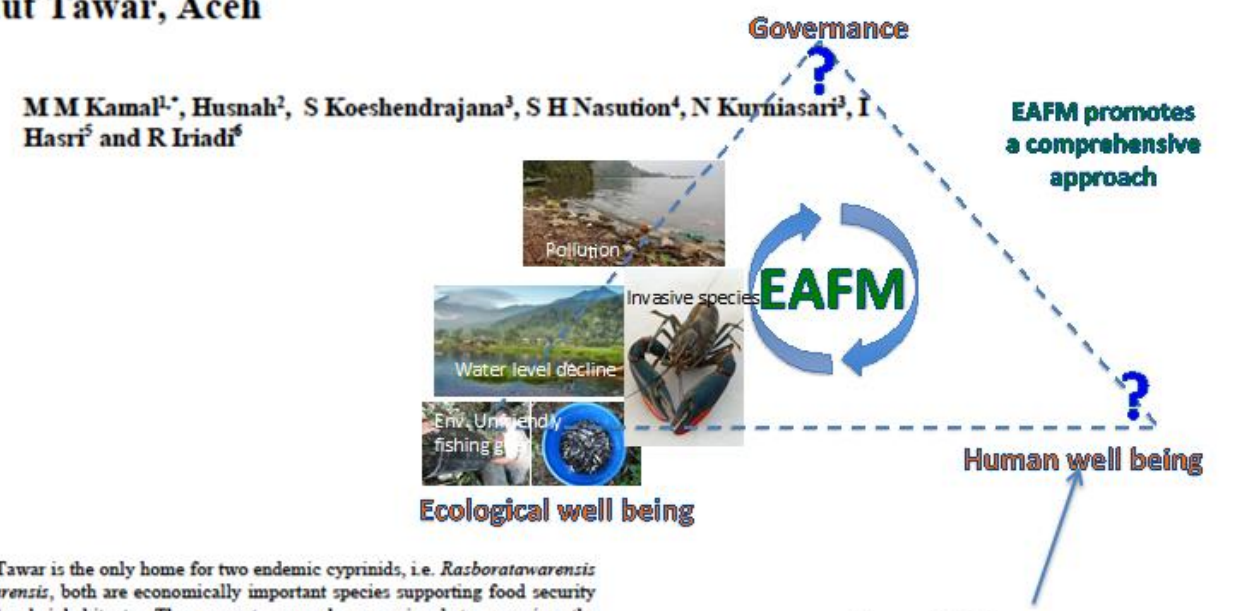

Abstract. Lake LautTawar is the only home for tho endemic cyprimids, Le. Rasboratawaronsis and livelihood to local inhabitants. The present research was aimed to eramine the and licability of EAFM, ecosystem approach to fisheries management in protecting endegic fishes in LLT. By refeming to standard module, the domains and its indicators were ranked and weighted. Having riven score to the domain, the composite domain and the sum of as values of all domains, the performance of fishery manazement could be presented as fla model Gap analysis was implied by contrasting EAFM's recommendation against current achievement with refer to defined indicator. The applicability of EAFM to sustaining enderic fishes was asessed by means impact anaris under the conario of three generic

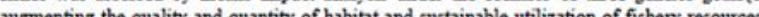
(2) prome the (2) promotion higher socio-economic benefit, and (3) improving function and synergy among all doable and that impact positively to sustining endemic specien. The challenges all doable and tat impact positively to sustion endemic species. The challenges in

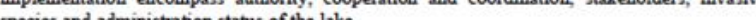

Regulasi??

Kelembagaan??

Kepatuhan??

Administrasi??

\section{Kesimpulan}

- Ikan endemik Indonesia menghadapi ancaman. Selain eksploitasi dan degradasi habitat, ikan invasif menjadi ancaman serius

- Upaya konservasi (pada semua tingkatan) perlu dirumuskan dan dilaksanakan secara terarah dan tepat

- Pengelolaan dengan pendekatan ekosistem untuk keberlanjutan perikanan endemik dapat menjadi alternatif perbaikan pengelolaan

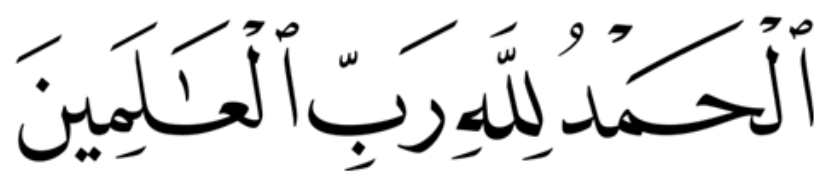

